\title{
Crossing Over: A Narrative Inquiry of One Man's Journey Across the Mexico/U.S. Border
}

\author{
Beth Garcia \\ Malvika Behl \\ Janet Tipton Hindman \\ West Texas A\&M University, USA
}

Doi: $10.19044 / 11 c . v 6 n o 3 a 2$

URL:http://dx.doi.org/10.19044/1lc.v6no3a2

\begin{abstract}
Illegal immigration is a highly debated issue in today's sociopolitical climate. While many U.S. citizens proclaim to be concerned about border security, there is also a great push to protect undocumented people who have lived in the United States most of their lives. Current research suggests that there has been an insignificant decline in undocumented immigration with most undocumented immigrants having been in the U.S. for more than ten years. With tightened border security, many immigrants endeavoring to cross the U.S./Mexico border today are forced to attempt more and more treacherous treks. Many immigrants lose their lives in these attempts; therefore, Coyotes (human traffickers) are sought to assist in finding unmonitored paths across the border. This qualitative narrative inquiry discusses the journey of one man crossing over from Mexico to the U.S. without authorization. Additionally, it the study highlights the personal trials he faced while trying to gain citizenship in the U.S. and provides insight into the issue of human trafficking while crossing over. The participant's narrative is then compared with Maslow's hierarchy of needs to illustrate the findings and implications.
\end{abstract}

Keywords: Illegal immigration, undocumented immigrants, human trafficking, Coyotes.

\section{Introduction}

From 2005 to 2013, an average of 450 immigrants died each year trying to cross the border without authorization from Mexico into the United States (Santos \& Zemansky, 2013). The chief forensic anthropologist at the Arizona Medical Examiner's Office, Bruce Anderson, found, "Less people are coming across, but a greater fraction of them are dying" (Santos \& Zemansky, 2013). This is due to an increase in border security necessitating immigrants to find and attempt more treacherous routes with the most dangerous stretches 
including the Arizona desert south of Tucson and the Rio Grande Valley region in Texas (Santos \& Zemansky, 2013) where the participant of this research crossed the border.

This narrative inquiry considers one man's journey across the Mexico/U.S. border while shedding light on the issue of human trafficking and the perils that occur to immigrants entering the United States without authorization. The voice of the primary participant is highlighted throughout the narrative to illustrate the personal trials he faced and his understanding that the way he entered the country was not the right way to gain citizenship. However, once here, his life changed unexpectedly where he could not return to his native country for years to pursue legal entrance. His narrative is then juxtaposed to Maslow's hierarchy of needs theory concerning human needs to illustrate the findings and implications of this study.

\section{Literature Review}

The term "undocumented immigrants" refers to foreign nationals who reside in the United States (U.S.) without legal immigration status (U.S. Legal Definitions). This definition is inclusive of persons who enter the U.S. without inspection and proper permission from the U.S. government and/or who have entered the U.S. with legal visas that are no longer valid (U.S. Legal Definitions). Amended numerous times with the most significant being the establishment of a new quota system in 1965, the Immigration and Nationality Act of 1952 (INA) also known as the McCarran-Walter Act is the main legislation governing immigration in the U.S. For INA purposes, there are different legal definitions or categories of "aliens": resident and nonresident, immigrant and nonimmigrant, documented and undocumented (Illegal Immigration Reform and Immigrant Responsibility Act of 1996).

A selective review of the literature on undocumented immigrants and illegal immigration encompassed related literature of sociopolitical attitudes and the impact of illegal immigration on the social, moral, political, and economic mores of current American society. The scope of this review intentionally excluded an exhaustive exploration of the widening effects of immigration and U.S. immigration policy on today's society, but presents a selective review of relevant literature of undocumented immigrants crossing over from Mexico to the U.S in light of increased employment opportunities through the American Dream.

In search of the American Dream, the general findings of the sources reviewed concluded that increased employment opportunities allowed undocumented immigrants the unique chance to create better lives for themselves and their families by crossing over to the U.S. As a driving force, economics caused many immigrants to decide to come to the U.S., albeit illegally, to ensure a better, safer, and more secure life. The. U.S. Department 
of Homeland Security reported a 203 percent increase of illegal crossings on the Southwest border from March 2017 to March 2018, tripling the crossings up 37 percent with the largest growth since 2011 (Daniels, 2018) General findings of the review for employment opportunities for undocumented workers concluded this influx of foreign-born laborers would reduce the economic opportunities for all laborers and would create stiffer competition in the labor market. Borjas (2013) surmised "theory also suggests that over time, as the economy adjusts to the immigrant influx, these wage effects will be attenuated" (p. 4). Having experienced numerous iterations and adopted various distinct methodological approaches over time, the academic literature approaches present dual claims "that immigrants have little impact on the wages of native-born workers, while other approaches conclude that such an effect exists and may be sizable" (Borjas, 2013, p. 4).

Recurring themes in the literature reflect current attitudes about immigration toward the effect(s) of illegal immigration on the economy; the support of, or opposition to, expanding enforcement measures; and immigration policy (Bean, Telles, \& Lowell, 1987; Espenshade \& Hempstead, 1996; Harwood, 1986; Wilson, 2001). Other emergent themes in the review were the dire need for comprehensive immigration reform and the profound impact of illegal immigration upon American society. Sources on illegal immigration and undocumented immigrants are readily and increasingly available in today's heightened political climate.

According to the most recent estimate from the Department of Homeland Security, "[t]here were 12.1 million immigrants living in the country illegally as of January 2014" (Robertson, 2018, p. 1). The Pew Research Center "estimates the number at 11.1 million in 2014, and the Center for Migration Studies says there were 11 million people in 2015 living in the U.S. illegally" (Robertson, 2018, p. 1). Since the census of 2010, U. S. Census Bureau Data reports, the undocumented population is approximately about eleven million out of 43 million immigrants that comprise about 14 percent of the total U.S. population of 323 million people." (Robertson, 2018, p. 1).

More than half of the undocumented immigrants currently living in the U.S. have resided there for more than a decade and nearly one-third are the parents of U.S.-born children according to the Pew Research Center (Lopéz \& Bialik, 2017). Central American asylum seekers, many of whom are minors who have fled violence in their home countries, make up a growing share of those who cross the U.S.-Mexico border. Under the 2008 anti-human trafficking law, these immigrants have different legal rights from Mexican nationals in the U.S. Minors from noncontiguous countries have the right to a deportation hearing before being returned to their home countries (Felter \& Renwick, 2018). 
In 2015, the Center for Migration Studies reported that although the aim of policies to reduce unlawful immigration focus upon enforced border security, individuals who arrive to the U.S. legally and overstay their visas comprise a significant portion of the undocumented population, outnumbering those who crossed the border illegally by six hundred thousand since 2007 (Felter \& Renwick, 2018).

The profound impact of illegal immigration has never been more apparent than in workplace employment. As America's leading immigration economist, Professor George Borjas (2013) contends in his study Immigration and the American Worker: A Review of the Academic Literature "[o]ne of the most contentious issues in the debate over immigration policy, both in the United States and abroad, is the question of what happens to the employment opportunities of native-born workers after immigrants enter the labor market" (p. 4). Borjas believes that "[e]conomic theory has straightforward and intuitive implications about what we should expect: Immigration should lower the wage of competing workers and increase the wage of complementary workers, at least in the short run" (p. 4).

Early studies of the economic impact of immigration upon the economy ignited the growth of a vast academic literature that attempted to "detect the presence and measure the size of the presumed wage effects" (Borjas, 2013, p. 4). The sociopolitical attitudes of the social, moral, political, and economic mores of current American society were evident in most of the sources of the literature review. The available sources of undocumented residents summarily concluded that undocumented residents of the U.S. have made a profound impact upon American society. The impact of this specific group of people within American society has produced extensive, valid, and often contentious discourse in the body politic of our country.

\section{Methodology \\ Narrative Inquiry}

This study was conducted as a qualitative, narrative inquiry where the researchers explored on a deep level the feelings and beliefs of the participants involved. The participants' voices were the strongest form of empirical evidence in this study. The researchers "considered 'real world measures' that are appropriate when 'real life problems' are investigated" (Lieblich, TuvalMashiach, \& Zilber, 1998, p. 5). Connelly and Clandinin (2000) succinctly defined narrative inquiry by stating,

Narrative inquiry is a way of understanding experience. It is collaboration between researcher and participants, over time, in a place or series of places, and in social interaction with milieus. An inquirer enters this matrix in the midst and progresses in this same spirit, concluding the inquiry still in the midst of living and telling, reliving, and retelling, the stories of the 
experience that make up people's lives, both individual and social. Simply stated...narrative inquiry is stories lived and told. (p. 20)

The researchers used discourse analysis within the narrative framework. Merriam (2002) suggested this as one possible strategy to use when engaged in narrative analysis. Gee (1991) suggested that "Discourse analysis examines the written text of the story for its component parts or assesses the spoken words by looking for intonation, pitch, and pauses as lens to the meaning of the text" (Merriam, 2002, p. 9).

Participants. There was one main participant included in this study and two secondary participants. Martin (pseudonym), the primary participant is an undocumented immigrant who entered the U.S. over twenty years ago. He was included as the primary participant due to his experience of crossing the Mexico/U.S. border illegally, and his narrative of this event was considered to be the primary data source within the research. The secondary participants included the immigrant's wife, Maria (pseudonym), and his immigration sponsor, Graciela (pseudonym). Their perspectives and roles were also integral components to this research as each played a significant part in the immigration procedures.

\section{Data Collection}

Data sources included an in-depth interview with each participant, prolonged engagement and observations of the participants for one year, and documents and records. The observations were collected as field notes; the documents included letters written on behalf of the participants to the U.S. Immigration authority; records included the main participant's immigration application and corresponding records from Homeland Security.

Interviews. In adherence to the sociocultural perspective through the lens of discourse analysis (Gee, 2001), the researchers conducted the interviews as socio-communication interviews (Rossman \& Rallis, 2003) to gain insight into the participants' stories that pertain to the research project at hand. To gain this insight, the researchers interviewed the immigrant who entered the U.S., his wife, and his sponsor. The interviews lasted two-three hours each.

Observations. Observations also revealed intricate parts of this story. "Observations lead researchers to interviews, suggest questions they had not anticipated and yield topics they might want to explore" (Rossman \& Rallis, 2003, p. 173). The researchers used prolonged engagement with the participants and conducted multiple informal observations throughout the course of one calendar year. They recorded observations using thick, rich description in a researcher's journal. "Thick description details physical surroundings, time and place, actions, events, words, and people on the scene" (Rossman \& Rallis, 2003, p. 175). 
Documents and records. Records included the lawyers' affidavits, applications for a visa and Green Card, and financial statements of the immigrant man and his wife that showed the process they encountered while filing for legal immigration status.

\section{Data Analysis}

Because the researchers were concerned with the participant's story concerning crossing the Mexico/U.S. border, the researchers used a narrative inquiry design for data analysis. Data analysis began immediately and continued throughout the entire research process. Erlandson (1993) stated, "The analysis of qualitative data is best described as a progression, not a stage; an ongoing process, not a one-time event" (p. 111). The researchers used the constant comparative method as suggested by Glaser and Strauss to produce grounded theory (1967).-The researchers began coding the data by having each of the three researchers complete a data analysis chart indicating the overarching themes and subthemes they found within the raw data. Then the researchers color-coded each of these categories. The researchers used open coding and the constant comparison method to code the data as they considered the information found in the interviews, researcher's journal, and field notes. The researchers then compared data analysis charts to indicate similar ideas that emerged in each chart; the researchers coded these until they found commonalities that produced themes.

As the researchers coded the data, they began to notice categories emerge as described by Strauss and Corbin (1990). Bogdan and Biklen (2007) described coding categories as "terms and phrases developed to be used to sort and analyze qualitative data" (p. 271). The researchers highlighted each pattern in a different color, which helped them differentiate between the ideas. From these categories, they determined the themes that occurred within the gathered research.

Transferability. While the onus of transferability comes from the reader, the researchers made transferability more likely by providing thick, rich description of the findings, which will also allow the readers of this study to come to their own conclusions about the data. "It is, in summary, not the naturalist's task to provide an index of transferability; it is his or her responsibility to provide the data base that makes transferability judgments possible on the part of potential appliers" (Lincoln \& Guba, 1985, p. 316).

\section{Narrative}

Martin initially tried to come to the United States using the proper channels and requesting permission to enter the country with permission and legal documentation. Martin served in the Mexican military and put in a request to go to the U.S. filling out the required paperwork and paying exorbitant fees. He put his parents' ranch in his name, so he had ties to Mexico 
and assets there; however, the paperwork was never sent through, and he never heard anything back after completing the process and paying the fees. His wife Maria shared,

He tried to do it the right way, the legal way and tried to get the right paperwork; he paid them money, but because they are so corrupt, they messed up his paperwork and sabotaged him, so he could not come in the 'right,' legal way. I feel like all the time people think it is so easy, but it's not.

After attempting to seek legal means of entering the United States, Martin decided he was left with no other choice but to enter illegally if he was going to make it into a country he saw as a place he might escape a life of poverty. Martin shared his story of crossing the Mexico-United States border and the perilous situations he endured to make it into the U.S. He shared, "It is really dangerous trying to cross the border. On those days, you come three to four people or maybe more, but when you get to the border, people know you have a little money to pay the Coyote." Coyotes are individuals involved in human trafficking and assist immigrants in crossing borders without legal authorization to do so (Walters \& Davis, 2011). These individuals, usually men, insist upon extortionate fees to provide forged papers, transportation, or passage across a border into a new country. In many cases, the Coyote will take the money and leave the immigrant stranded left with nothing (Walters \& Davis, 2011). Martin stated that people in the border towns know that they have some money when they get there, so there is a high probability of being robbed. He shared,

They are going to tell you, give me your money, give me your wallet, give me your shoes, and by the way, I like the shirt you have on, take that off too. That is lucky, someone else might leave you with no clothes and kick (beat) you on the street.

Martin then explained the process of leaving his home country and the journey he took to enter the United States. He indicated that the first step was to get to the bus station in a border town and then connect with someone who knew the Coyote. Sometimes immigrants attempting to cross the border may need to get on the bus again and travel to another town thirty to forty-five minutes away. The person who knows how to locate the Coyote will tell the small group where to stop and wait. Once the group is connected to the Coyote, money and property are exchanged; however, that is not the end of the transaction for the assistance in crossing the border. In many cases, the Coyote will deliver the immigrants crossing into the hands of his partner where an indentured servitude situation is prevalent. If the immigrants survive the journey and are not caught, they must work for the Coyote's partner in the U.S. to pay off the rest of their debt. 
Once Martin's small group connected with the Coyote, they began walking on the Mexican side of the border close to the river. Before leaving, Martin was told to take a plastic bag and an extra pair of socks and underwear. The group hid until they had a chance to cross the river; when all was clear, they stripped down to their underwear placed their clothes in the plastic bags, and crossed the river. Martin shared, "When you cross the river, the water is cold (emphasizes cold); you make it to the U.S., get on your dry clothes from the bag, and start walking with the Coyote, because the Coyote knows the trails." When questioned about how far and long his group walked, Martin responded that they walked for three full days and mostly at night. $\mathrm{He}$ described fields filled with rattlesnakes and not being able to see them, but they could hear a chorus of rattles surrounding them. He described the fear of walking through these fields in the dark, as they never knew how close they were to being bitten and dying. Dying was a real possibility for Martin and the small group that crossed with him. They faced countless dangers beyond being caught and sent back to Mexico. They all placed their lives on the line to make it into the United States. In another dangerous encounter, Martin described a field filled with one thousand bulls; as soon as they entered, this entire herd began to chase them, pawing the ground, snorting, and ready to gore any man they could catch. Martin and his group ran to escape them. Once they made it to safety, the Coyote informed them that these bulls had never chased his groups before, so he knew that they were there and that it could have been a dangerous situation, but decided to lead Martin and the other men through this path anyway.

Martin also described the discomfort of the journey and what he endured during this three-day trek. With a disgusted look on his face, Martin relayed, "We run out of water; we find this pond with green water; they cows pee and shit in it." He shakes his head and continues, "Right there was horrible; the cows pee and shit, but you are thirsty and drink right there. We started to get dehydrated, and it starts with a headache, but we found this water, so that was good." Martin described the emotions that went through him during this travel. He was afraid of being caught, he worried about having food, but the main thing that concerned him was the water. Beyond hunger, exhaustion, and thirst, Martin and his group suffered from physical ailments such as blisters that hindered their walking such a far distance. "I have blisters on my feet (showing the size with his fingers making a circle) about two inches around. When we hid right there (in a hunter's deer blind), this place have some carpet, so I take my knife and make a sole for my tennis shoes from the carpet." After securing his shoes that were physically falling apart from the rough terrain and sheer distance the group had travelled, Martin described the pain he endured. 
Then my blisters, they were open already, and the skin was folded to the side. What I did, I grab a needle with a sewing string because that was one of the main things they told to bring with us - cream, needle, and sewing string. I pulled the skin back and sewed it together, so I didn't walk on bare meat.

Martin relayed that the small group rested after this; however, they had begun to run out of water again. When they had stopped at the cow pond, they had filled canteens and bottles with the nasty, green water, but even that ran dry very quickly. The Coyote encouraged this group by telling them that they just had one more day and night in the wilderness; then they would meet up with one of his associates who would bring a car and drive them into a city. Martin got a rash that covered his body and made it painful for him to move much less walk and climb over barriers. On their last night of travel, a powerful cold front moved into Texas, "and we just pull up body to body to try to keep us warm at night. The coyotes (the animals) howl close to us, wild hogs, but we made it." Each of the men suffered extreme discomfort; Martin conveyed, "That night was horrible; was freezing. I don't know what to do. If I put my shoes on, I can't handle the pain with them on or the cold with them off." The next day when the sun came up, Martin and his group knew they just had to travel seven more miles to a small Texas town where someone would bring them a car.

Martin and his small group made it to a little town around nine that evening; when they got there, the Coyote demanded that Martin give the Coyote his shirt because it looked the best out of everyone's in the group. The Coyote had to walk to a gas station and pick up a car that had been left for them with the keys hidden in the gas cap. Martin remembered that the weather was very bad, and they had to hide in a ditch and wait for the Coyote to come back for them. The Coyote informed Martin and the rest of the men that he would flash the lights three times when he came back so that they would know it was him. This would be their signal to run from the ditch and jump into the running car. It took a long time for the Coyote to return with the car; in fact, Martin admitted to thoughts running through his head where he wondered if they had been double-crossed and abandoned. Finally, a car pulled up close to where the men were hiding in the ditch; however, it did not flash its lights. Martin and the rest of the men did not know what to do, but then the Coyote opened the driver's door and yelled out, "Let's go, vamanos!"

That night, the Coyote drove past San Antonio; then they headed towards Houston. This is the first time that Martin shared actual names of cities in which his group passed through. Up until this point, he would only give vague descriptions of towns and landmarks. As they were heading towards Houston, Martin recalls that the water pump on the car failed. The Coyote kept driving until he could pull into a rest area along the highway. 
Once they got to the rest area, the Coyote told them to get out of the car and go hide again. The Coyote walked to a gas station somewhere in the area and made a phone call to his associates who promised they would send another car, but it took about three hours to accomplish this. During this entire time, Martin and the other men with him were hiding with wild thoughts running through their heads. "We don't know this country, we don't speak English, and it had been four days since any of us had a shower; it was horrible." Finally, the Coyote returned with another car and took Martin and the other men to Houston.

When asked why he endured so much to enter a country without authorization, Martin responded,

There are two reasons. One of them is because where I come from, is a lot of poor people. I saw them suffer for a meal. They don't have shoes; they don't have clothes. The poverty is the main thing; it doesn't matter if we get paid under the table, it is still more than we ever had.

Besides poverty, Martin discussed safety as another reason that immigrants enter the U.S. by sharing, "The cartels and the violence make people scared to stay. I saw many friend and family hurt or killed, so they leave to protect their family." Once the men reached Houston, their journey was not over. They each still owed the Coyote and had to work as indentured servants until the debt was paid. Martin remembered, "When I get here and started working roofing, I need to be up at 5:30 in the morning; I live with twelve other people in one apartment with two bedrooms and one bathroom. To take a shower, you need to hang your towel on the wall to get in line for it." Martin stated that he worked as a roofer with a crew that all came into the United States in relatively the same manner and all owed a Coyote money; their boss and foreman of this crew, loaned each of the men in this crew money to pay the Coyote when they reached Houston for their passage. The men worked fourteen-hour days and were paid roughly sixty dollars a day, which equals about four dollars per hour. This was before the foreman took out his fees for paying off the Coyote. "I worked for the guy who loaned me the money to pay the Coyote, so I was stuck with him." He asked, "What was I supposed to do? So I work for him until I finished pay the Coyote. And he (the foreman of the roofing crew) kept taking the money out of my pay because I still owe him." When asked how long it took to pay this debt and be able to leave the crew, Martin replied, "It took six months of this work to pay him off. I left after I paid him off and then came to West Texas. I knew some people who went there."

Martin did not have any friends or family in West Texas, but he knew some other people who had immigrated to the region. Once he paid his debt for crossing the border, Martin made his way to West Texas. There, he began to work on a construction crew, and again, he was paid little and had no 
benefits due to his immigration status. After a few months, he met a girl named Maria at a friend's house. They struck up a friendship and began talking. After a few months the couple began dating and fell in love. Martin and Maria have now been married for thirteen years and have three children. She is a U.S. born citizen, and so are their three children, but this was not enough for Martin to gain legal, permanent residency.

Undocumented citizens have to go through a process of receiving a visa and green card before receiving citizenship. Citizenship is not automatically granted to undocumented immigrants who marry U.S. citizens (U.S. Citizenship and Immigration services, 2017). According to the Illegal Immigrant Reform and Immigrant Responsibility Act of 1996, undocumented immigrants have to return to their home country for six months to ten years, before applying for legal status. This process would have been difficulty for Martin since he would have had to travel back to Mexico, leaving his wife and children behind.

Therefore, Martin ended up waiting ten years for the laws to change so that he could apply for permanent, legal residency without having to return to his home country for years. He and his family employed a local lawyer who specializes in immigration law and has to date paid over $\$ 10,000$ U.S. dollars. This is a substantial sum of money for a family of five living on one income. Martin and his wife, Maria, had to complete extensive background, psychological, and health checks to even apply for an Immediate Relative Visa (IR1).

Martin had to return to Mexico for a two week period to initiate the immigration process. Martin reminisced about the day he pleaded to be allowed to re-enter the United States but this time as a documented immigrant.

When it was my turn, I remember being in line praying to God, let me come back home with my family. The man yells, "Next!" He then asks my name, so I tell him. This man at the consulate then asks me, "how you cross" (the border), and I told him the field; they call it the Monte. He told me, "Look me straight in the eyes and tell me have you had problems with the law in the U.S.", and I told him "no". The man asked, "have you ever been arrested," and I told him "no." "Who is your sponsor," and I told him "Graciela Jimenez, a good friend of the family;" I told him, "We just call her Gracie." So this man, he have my Mexican passport, and I still remember he grab the seal and stamped on my passport and say "you can pick up your package in four to eight days... Welcome."

Martin tears up at the recalling of this story. He told the man at the consulate,

Thank you so much. You don't even know how you changed my life and my family's life today, and he just smile. I remember walking out of that place; I can't wait to get to the hotel to tell my wife and my kids we get to go back together to Texas. I returned to the consulate five days later 
to pick up the package with my visa and my legal residency papers, so we can go back across the border to the United Sates. The traffic was horrible,

so I told my wife, I am just going to walk and wait for you on the other side.

Martin again walked across the Mexico/U.S. border, but this time legally with the proper documentation. When asked how he felt entering the U.S. legally, Martin looked up at the ceiling and sighed. He replied, "Freedom. I walked across the border with my arms lifted to the sky, and I raise my hands and say, Thank you God; we all go back together (he begins sobbing as he shares this memory); it's a feeling that is hard to explain."

\section{Theoretical Framework}

The theory guiding this research stems from Abraham Maslow, an expert in the field of psychology. Bearing in mind the seminal work of Maslow (1943) concerning humans' hierarchy of needs, the researchers considered the effects of undocumented immigration from the participant's perspective paralleled to Maslow's hierarchy of needs that include physiological, safety, love/belonging, esteem, and self-actualization. Maslow (1943) said that there are goals that each individual needed to meet to move to the highest level of the hierarchy. Goals help create motivation and these focus on more long-term issues rather than partial issues (Maslow, 1943). The goals are supposed to be an "end rather than the means to an end" (Maslow, 1943, p. 370). The individual needs to fulfill some prerequisites before working on their basic needs, like

...freedom to speak, freedom to do what one wishes so long as no harm is done to others, freedom to express one's self, freedom to investigate and seek for information, freedom to defend one's self, justice, fairness, honesty, orderliness in the group (Maslow, 1943, p. 383).

After fulfilling the prerequisites, Maslow (1943) reported that individuals need to fulfill their physiological needs, safety needs, love needs, and esteem needs, leading them to reach self-actualization. The physiological needs include the need for food and water and are amongst the most basic needs for individuals. The safety needs amongst adults includes the need to feel safe in their environment from "wild animals, extremes of weather, criminals, assaults and murder, and tyranny" (p. 379) and financially such as having a job, a positive bank balance, and insurance (Maslow, 1943). The love needs arise when individual hungers for affection and make it a goal to receive it (Maslow, 1943). The love to satisfy this need could be received through friends, romantic relationships, and/or family by both receiving and giving love (Maslow, 1943). The next part of the hierarchy is the esteem needs of an individual. All individuals in the society have the need to achieve and be respected by one's self and others (Maslow, 1943). As individuals meet all 
their needs they reach, self-actualization, which is a term coined by Kurt Goldstein (1939). Maslow (1943) reported that it means, "What a man can be, he must be" (p. 382). Self-actualization is the need for an individual to achieve one's utmost potential and become what they are capable of becoming (Maslow, 1943).

\section{Findings and Implications}

The impact of immigration and the laws on undocumented immigrants, their families, and friends can be extensive. The process of moving to a new country and building a life can be stressful and when one adds the immigration laws and its impacts, this can put a strain in the immigrant's personal and familial life as seen in Martin's narrative.

\section{Personal - Safety and Physiological}

According to Maslow's (1943) theory, personal actualization stems from the person being safe and having physiological needs met. On a personal level, there were significant implications for the participants of this study. They faced the fear of being torn apart as a family. In this situation, Martin and his family had no control over the situation, which caused extreme emotions and high anxiety. Personally, for the participants, their safety needs were impacted. The participant, while undocumented and in the process of immigration, was in fear of being deported. This shows in the sponsor's interview who said "...I was driving once and speeding, and he (Martin) asked me to slow down to the speed limit as he was afraid if we were pulled over that he would be deported."

This constant fear of deportation and not being able to provide for one's family can affect an individual's physiological and safety needs. Martin shared, "If I was deported, her (his wife, Maria) and my kids would live on the street; she would never go over there (Mexico)." Inability to meet these needs can cause an individual to feel unstable and insecure. In her interview, Martin's wife, Maria, shared, “...I have night trembles and wake up with my heart racing; there is a lot of stress not knowing what is going to happen in my life." Every individual has a right to feel safe and secure and as the sponsor relayed, "... a place where they can raise a family without fear of starving or genocide."

\section{Familial - Safety, Love, and Belongingness}

In today's world, the feeling of belonging to a family can make an individual feel safe and centered. The fear of being separated from their family at any time can be difficult for both the undocumented citizen and their family. In this narrative inquiry, Maria stated, "If he (Martin) was deported for his immigration status, the family would either have to go to a country that they 
have no ties to, no relatives in, no support, and the children would not receive the same type of education.

Maria, a US citizen, stated that if her husband was deported, she would lose any kind of monetary support and most importantly lose the emotional support that she currently has. Maria shared from her letter to petition for Martin's permanent legal residency visa,

Any separation would cause my children and me great emotional stress that would definitely affect our mental health in a very negative way. I would be extremely depressed if we were separated. I would have to deal with the mental anguish of having no support or help with the household, childcare, or financial responsibilities. Most importantly, I would be devastated by the separation from my husband; he is more than just my spouse, he is my life partner, confidant, and best friend.

Fearing that their loved one can be removed from their life at any time can make a person feel that their love and belongingness needs may hang in the balance. Alongside that, the fear of being removed from one's own country and be moved to another can be very stressful as well. A person who is scared for their love and belongingness needs will never be able to reach their full potential, be it the U.S. citizen or the undocumented citizen.

Additionally, if there are family/friends who are willing to spend their time and help the immigrant seek legal, permanent residency, that can cause an individual to feel loved. In her interview, the sponsor stated, "It has cost me some time; I have spent many hours gathering documents and writing letters on Martin's behalf, but I believe it is my responsibility to help him attain his citizenship." In a political environment that is focused on deporting undocumented citizens, having one person's support and help, can make an individual feel loved and supported; this is evidenced again by the sponsor who stated,

I am scared for immigrants and refugees coming to the United States. I know what the process is like, and it is difficult and many times unfair and expensive. Many times refugees and immigrants try to get to a country like the U.S. in the hopes of creating a better life and leading a safe life. A place where they can raise a family without the fear of starvation or genocide. Today's political climate has taken ten steps back from where we were during the era of Civil Rights.

\section{Financial/Medical - Physiological}

As evidenced in the narrative concerning Martin's crossing the border, he lacked basic physiological needs such as shelter, food, shoes, safety, and clean water. During the course of the immigration process, the family as a whole won and lost some battles concerning basic physiological needs as well. One of the battles that proved difficult was the issue of health insurance. The 
family was removed from Medicaid because once Martin attained a sponsor, the sponsor's income was considered as part of the family's assets. This is a stipulation so that Martin can prove that he will not take government assistance as he engages in the process of citizenship. This necessitated that the family had to pay out of pocket for the children's insurance, something they had not had to do before. Before Martin was a documented citizen, Maria was able to file and qualify for Medicaid for their three children. Graciela reminisced about this issue in her interview by sharing,

Maria called me crying one afternoon; she was completely distraught. She told me that Medicaid cancelled her children's health coverage because they were basing eligibility on my income. She really needed health care for her children. I just felt so badly for her when she called me. I felt like it was my fault. I was frustrated because my insurance wouldn't allow me to put them under my coverage, yet the government stated I was responsible for them. It was like a Catch 22 where I am responsible, but I can't do anything about it. The system seems to be set up where it makes it so difficult for undocumented immigrants to seek and receive legal status that they just give up.

By having to pay for the immigration process and then pay for health insurance, it put a great strain a financial strain on this family. Maria stated that the legal and immigration fee cost about $\$ 10,000$ and eventually they had to travel to Mexico, which was a separate cost. Over the course of time, a person who is unable to afford this but has to complete the process would have a hard time providing the basic needs or physiological needs to their family like food and shelter.

Maria shared, "I feel like if he would have been deported, I would have been a single mom trying to raise three kids by myself," which means Maria, who was a stay at home mom would have had to work while taking care of the three children and meeting all their physiological needs. During the interview, Maria did state how difficult she envisioned that being and that she might lose the house if her husband was deported. If one's basic needs of food and water are not met, s/he is not able to move up the hierarchical pyramid to reach his/her full potential of self-actualization.

\section{Community/Societal - Love and Belongingness}

In the current political environment, the word "undocumented" has been replaced with "illegal," which comes with its own negative connotations. Individuals might not feel comfortable coming out and saying "I am undocumented" in front of friends or extended family, due to the fear of being ostracized or reported to the U.S. Immigration and Custom Enforcement (ICE). During her interview Maria shared, "Most people like Martin, and I didn't want them (family, friends, and acquaintances) to change their opinions of him because of his status here." She felt that her husband would be judged 
not for who he is but because of his status in the country. Hiding a big part of your life with close family and friends just to keep them in one's life can be difficult. This takes away from an individual's basic needs of freedom to speak and express themselves; since people already have negative impressions of undocumented citizens, they are concerned about being treated fairly and justly. When asked how the term "illegal" made the participants feel, each shared their perspective. Graciela commented,

That term makes me feel furious. I cannot tell you how many U.S. citizens I have heard say things like, "go back to your country," "those people are not wanted here," "we don't have enough resources for them," "they are ruining our country," and my all-time favorite, (rolls her eyes) "You are in America, learn English." I wish we as Americans would base our statements and judgments on more facts than demagoguery.

Maria relayed,

Some things don't bother me, some things do. I feel like we have our own lives as individuals, and we don't know the lives of others, and we don't know what brought them here. I am not saying every person who comes over illegally is a good person or should stay, there are good and bad, but don't judge them on the action. Judge them on the person they are.

Martin shared that he has been called all kinds of names and that these are hurtful and defamatory; in fact, he even refers to himself as some of these names from hearing them so often.

I am a wetback; that's what they call me. It makes me feel sad. When they say to me illegal because we don't have one ID and we don't have a social security, make me feel sad. I think that everybody deserve a chance for this life; this country is made with immigrants, and I can't wait to become a U.S.A citizen.

\section{Conclusion}

Through the qualitative paradigm, the narrative inquiry approach helped the researchers of this study understand the process of crossing into the United States without documentation and the enduring immigration process as an undocumented citizen. Martin faced a plethora of problems crossing over the U.S./Mexico border and entering the U.S., which included dangerous and grueling physical exertion hiking through the wilderness, paying the Coyotes, and struggling to make ends meet and find acceptance once inside the U.S. to make a better life for himself and his family. As Martin relays in his letters to the immigration authority, he realizes that he did not follow the proper procedures to enter the country; however, once inside the country, his life took unexpected and permanent turns. As he was working on his new life as an undocumented citizen, he became a husband and father. He created friendships 
that produced friends such as Graciela who vouched for him as he went through the immigration process, which was emotionally and financially draining on him and his family. Ultimately, this narrative inquiry illustrated the connection between Maslow's hierarch of needs and the journey that one undocumented immigrant embarked upon to first cross over into the United Sates and then to go back to his home country to re-enter with proper documentation. His narrative is a powerful story of determination and the undying human spirit seeking a better life and the American Dream. It is the researcher's hope that this article sheds light on the difficulties of the immigration process and humanizes the act of illegal immigration so that laws are more standardized and more attainable for those wanting to enter using the appropriate channels.

\section{References:}

1. Bean, F.D., Telles, E.E. \& Lowell, B. L. (1987). Undocumented migration to the United States: Perceptions and evidence. Population and Development Review 13(4): 671. December 1987.

2. Bogdan, R. C., \& Biklen, S. K. (2007). Qualitative research for education: An introduction to Theories and methods ( $5^{\text {th }} \mathrm{ed}$.). Boston: Pearson Education.

3. Borjas, G. (2013, April). Immigration and the American worker: A review of the academic literature. Center for Immigration Studies.

4. Connelly, F. M., \& Clandinin, D. J. (2000). Narrative inquiry. San Francisco: Jossey Bass Inc.

5. Daniels, J. (2018, April). "'Illegal' crossings at the U.S. southwest border triple in march from a year ago." Retrieved on September 3, 2018 from

6. https://www.cnbc.com/2018/04/05/crossing-attempts-at-ussouthwest-border-triple-in-march-from-year-ago.html.

7. Espenshade, T.J., \& Hempstead, K. (1996). Contemporary American attitudes toward U.S. immigration. International Migration Review. Summer 30(2): 535-570.

8. Erlandson, D., Harris, E., Skipper, B., \& Allen, S. (1993). Doing naturalistic inquiry: A guide to methods. Newbury Park, CA: Sage Publications.

9. Felter, C., \& Renwick, D. (2018, March). The U.S. immigration debate. Renewing America: Council on foreign relations. Retrieved on September 3, 2018 from https://www.cfr.org/backgrounder/usimmigration-debate- 0 . 
10. Gee, J. P. (1991). What is literacy? In C. Mitchell, \& K. Weiler (Eds.), Rewriting literacy: Culture and the discourse of the other (pp. 3-11). New York: Bergin \& Garvey.

11. Gee, J. P. (2001). Reading as situated language: A sociocognitive perspective. Journal of Adolescent and Adult Literacy, 44(8), 714725.

12. Glaser, B., \& Strauss, A. (1967). The discovery of grounded theory. Chicago, IL: Aldine Publishing.

13. Goldstein, K. (1939). The organism: A holistic approach to biology derived from pathological data in man. New York, NY: American Book Company.

14. Harwood, E. (1986). American public opinion and U.S. immigration policy. The Annals of theAmerican Academy of Political and Social Science, 487, 201-212.

15. Illegal Immigration Reform and Immigrant Responsibility Act of 1996, Public Law 104-208, 104th Cong. 1st sess. (September 30, 1996).

Retrieved

from https://www.gpo.gov/fdsys/pkg/PLAW104publ208/ html/PLAW104publ208.htm.

16. Lopéz, G., \& Bialik, K. (2017, May). Key findings about U.S. immigrants. Pew Research Center: Facttank. Retrieved on September 3, 2018 from http://www.pewresearch.org/facttank/2017/05/03/key-findings-about-u-s-immigrants/.

17. Lieblich, A., Tuval-Mashiach, R., \& Zilber, T. (1998). Narrative research: Reading analysis and interpretation (Vol. 47). Thousand Oaks, California: Sage Publications.

18. Lincoln, Y. S \& Guba, E. G. (1985). Naturalistic Inquiry. Beverly Hills, CA: Sage.

19. Maslow, A. H. (1943). A Theory of Human Motivation. Psychological Review, 50(4), 370-96.

20. Merriam, S. B. (2002). Qualitative research in practice: Examples for discussion and analysis. San Francisco, CA: Jossey Bass Publishers.

21. Robertson, L. (2018, June). Illegal immigration statistics. The Wire. Retrieved on September 3, 2018 from https://www.factcheck.org/2018/06/illegal-immigration-statistics/.

22. Rossman, G., \& Rallis, S. (2003). Learning in the field: An introduction to qualitative Research ( ${ }^{\text {nd }}$ ed.). Thousand Oaks, CA: Sage Publications.

23. Santos, F. and Zemansky, R. (2013, May 20). Arizona desert swallows migrants on riskier paths. 
24. The New York Times. Retrieved from http://www.nytimes.com/2013/05/21/us/immigrant-death-rateriseson-illegal-crossings.html.

25. Strauss, A. \& Corbin, J. (1990). Basics of Qualitative Research: Grounded Theory Procedures And Techniques. Newbury Park, CA: Sage Publications.

26. U.S. Legal Definitions. Illegal immigrant. Retrieved on September 3, 2018 from https://definitions.uslegal.com/u/undocumentedimmigrant/.

27. Walters, J. \& Davis, P.H. (2011). Human trafficking, sex tourism, and child exploitation on the southern border. Journal of Applied Research on Children: Informing Policy for Children at Risk, 2(1), 1-17.

28. Wilson, T. C. (2001). America's views on immigration policy: Testing the role of threatened group interests. Sociological Perspectives, 44(4). 485-501 